\title{
Television-viewing Habits in a Preschool Age Clinical Population with Autism Spectrum Disorders and Other Clinical Groups
}

\author{
Okul Öncesi Dönem Otizm Spektrum Bozukluğu ve Diğer Klinik \\ Gruplarda Televizyon İzleme Alışkanlıkları
}

Abdurrahman Cahid ÖRENGÜL iD, Vahdet GÖRMEZ iD

Department of Child and Adolescent Psychiatry, Bezmialem University School of Medicine, İstanbul, Turkey

\section{ABSTRACT}

Objective: We aimed to compare the television (TV)-viewing habits in a clinical sample of children with autism spectrum disorders (ASD) and those diagnosed with language delay, disruptive behavior disorders, and depression/anxiety and those who had no clinical diagnosis (no dx).

Methods: The main outcome measures involved the onset and frequency of TV viewing and the content (type of programs) and context (co-viewing) of viewing habits. A comprehensive psychiatric assessment, the Childhood Autism Rating Scale (CARS), which is a clinician rated psychometric tool, and the Aberrant Behavior Checklist-Community $(\mathrm{ABC})$, which is a parent rated questionnaire, were used for diagnostic evaluation.

Results: In a total of 148 preschool children (range $=10-60$ months; mean=42.02, $\mathrm{SD}=10.23$ ), the onset of TV viewing before the age of 12 months differed significantly among the groups $(\mathrm{p}=0.038)$. The ASD group had the highest percentage of children who started watching TV before 12 months $(56.7 \%)$ and of those viewing adult (non child) programs (87.5\%). The content of viewing (watching adult programs) and duration of playtime with siblings significantly differed between the groups ( $\mathrm{p}=0.003)$.

Conclusion: Children with ASD have an earlier onset of TV viewing and watch more adult programs. Further research is required to examine the relationship between early exposure to screens and psychiatric diagnoses, particularly in those with impairment in social interactions and language.

Keywords: Autism spectrum disorder, children, preschool, television, language delay

\section{öz}

Amaç: Bu çalışmada, Otizm Spektrum Bozukluğu (OSB) olan okul öncesi yaş grubundaki klinik örneklemde televizyon izleme alışkanlıklarının dil gecikmesi, yıkıcı davranış bozuklukları, depresyon/anksiyete gibi psikiyatrik tanı grupları ve tanı almayan çocuklar ile karşılaştırmalı olarak araştırılması hedeflenmiştir.

Yöntemler: Gruplardaki çocuklar televizyon izlemeye başlangıç yaşları, günlük TV izleme süreleri, ortamı ve izledikleri programların türü ve içeriğini kapsayan alışkanlıklar açısından karşılaştırıldı. Psikiyatrik tanılandırma için, ayrıntılı psikiyatrik muayene, klinisyen tarafından skorlanan Çocukluk Otizmini Derecelendirme Ölçeği (ÇODÖ) ve ebeveyn tarafından skorlanan Sorun Davranışlar Kontrol Listesi (SDKL) kullanılmıştır.

Bulgular: Okul öncesi dönemdeki 148 çocukta (yaş aralı$\breve{g} 1=10-60$ ay, ortalama $=42,02, S S=10,23)$ yapilan değerlendirmede, televizyon izlemeye 12 ay ve öncesinde başlama $(p=0,038)$, yetişkin programları izleme $(\mathrm{p}=0,003)$ ve kardeşleri ile geçirilen oyun süresi ( $\mathrm{p}=0,003)$ açısından gruplar arasındaki fark istatistiksel olarak anlamlı bulunmuştur. Bir yaşından önce TV izlemeye başlama $(\% 56,7)$ ve yetişkin programları izleme oranı $(\% 87,5)$ OSB'li çocuklarda diğer gruplara göre daha fazla bulunmuştur.

Sonuç: Bu çalışmada, OSB'li çocukların diğer klinik gruplara göre daha erken yaşta televizyon izlemeye başladıkları ve daha fazla yetişkin programları izledikleri gözlemlenmiştir. Özelikle sosyal etkileşim ve dilde bozulma ile seyreden psikiyatrik tanı gruplarında ekrana erken yaşta maruz kalmanın etkilerini gösterecek daha güçlü çalışmalara ihtiyaç vardır. Anahtar kelimeler: Otizm spektrum bozukluğu, çocuk, okul öncesi, televizyon, konuşma gecikmesi

\section{Introduction}

Extensive offerings of household media have been reported to expose children to 3-6 hours of daily screen viewing, which is the longest single activity, excluding sleeping (1-3). This finding indicates that many children aged $<2$ years spend onethird of their waking hours watching screens (4). It appears that the excessive exposure to screens is not only confined to the children in the home setting. In a large scale national survey conducted to examine the predictors of TV viewing in a home-based child care compared with the licensed child care settings, Christakis et al (2006) reported that as many as 89\% of children in the former group and 35\% of those in the latter group regularly watched television (TV). Approximately $30 \%$ of the programs for children in home-based child care settings were noted to be "non-educational" (3). Almost on-

Cite this article as: Örengül AC, Cörmez V. Television-viewing Habits in a Preschool Age Clinical Population with Autism Spectrum Disorders and Other Clinical Groups. Bezmialem Science 2018; 6: 94-9. 
ethird of preschool children and threequarters of adolescents in the USA were reported have TV sets in their bedrooms, which has been attributed to the dictation of market forces on families $(1,2,5)$. Less than four decades ago, children would begin to watch TV at around 4 years of age, but this figure seems to have dropped to 5 months (6).

Research-based data about the impact of TV viewing on young children emphasizes the effect of content (what they watch) and context (how they watch) of TV viewing rather than the duration. Exposure to TV in infancy limits the caregiver's verbal interactions with the infant independent of the types of media content, except for child-oriented educational programs that parents co-viewed with their infants. However, the authors noted that such programs with educational content were not preferred over other programs for co-viewing (7). The mediating effect of social interaction with adults during learning process has been reported in interesting research designs. For example, infants were able to learn Chinese from a native speaker; however, the same speaker's videotape recording was not sufficient to learn the language. The authors concluded that the learning process of the infants aged 9-10 months is enhanced by social interaction and not by long-term listening (8). A negative association between vocabulary acquisition and viewing of baby DVDs/videos at 8-16 months of age has also been reported. Every hour of viewing was noted to be associated with almost a $20 \%$ drop, which corresponds to a difference of about 6-8 words for a typical child on the MacArthur Bates Communicative Development Inventory (9). Similar results were replicated in a study from Thailand (10), which demonstrated that TV viewing of 2 or more hours per day before the age of 12 months was associated with a six-fold increase in the likelihood of delayed language acquisition. Similar deleterious effect also applies to the commonly known educational programs designed for 3-year-old children, such as Sesame Street, which has also been associated with delayed language acquisition (11).

In addition, studies have emphasized a possible link between attention problems and TV viewing. For example, in an observational study with $>1300$ children, TV viewing before the age of 3 years and problems with inattention at the age of 7 years was noted to have a modest association. An increase of one standard deviation (SD) in the number of hours of TV viewing at 1 year of age was reported to be associated with a $28 \%$ increase in the probability of having inattention problems at 7 years of age (12).

Despite the relatively large amount of research-based data on the impact of exposure to screens, the relationship between TV viewing and autism spectrum disorders (ASD) has been neglected in research. The only study where such a relationship was researched demonstrated that children with ASD started watching TV significantly earlier than the control group $(\mathrm{p}<0.0001)$, and they spent more time viewing TV compared to those with language delay $(\mathrm{p}<0.0001)$ and controls $(\mathrm{p}<0.0001)$ (13). A psychometric tool to assess symptoms specific to ASD was however not used in the mentioned study.
To our knowledge, the present study is the first that examined TV viewing habits in a sample of preschool children with ASD who presented to a child psychiatry outpatient clinic. Therefore, our aim was to compare TV viewing habits in children from different diagnostic groups, while focusing on those with ASD and language delay. Based on the existing evidence, we hypothesized that the TV viewing habits of preschool children with ASD and language problems differ from the other clinical groups.

\section{Methods}

\section{Participants}

A total of 148 preschool age children [male $(\mathrm{m}) /$ female (f): 104/44] aged younger than 60 months (range $=10-60$; mean $=42.02, \mathrm{SD}=10.23$ ) were recruited from the Bezmialem University Child and Adolescent Psychiatry Clinic between July 2015 and February 2016. Those with mental retardation were excluded. The average age of mothers was 31.87 years $(\mathrm{SD}=5.24$; range $=17-48)$ and that of fathers was 35.28 years $(\mathrm{SD}=5.56$; range $=18-52)$. Twenty one percent of mothers were employed; $27 \%$ of the mothers and $28 \%$ of fathers were university graduates, whereas $31.4 \%$ of mothers and $34.5 \%$ of fathers were high school graduates.

\section{Procedure}

Parents completed the sociodemographic data tool, where developmental variables were also enquired. Details such as the age of both parents; monthly income in the household; prenatal variables, such as prenatal diseases, and drug and tobacco use during pregnancy; birth weight; problems about delivery; and postpartum depression in mothers (based on parental report) were also asked in the data tool.

Children underwent a comprehensive clinical assessment by two experienced child and adolescent psychiatrists, based on the practice parameters for psychiatric evaluation in early childhood (14). Diagnoses were confirmed using the criteria set in the Diagnostic and Statistical Manual of Mental Disorders, Fifth Edition (15). The assessment of children with ASD and language delay included assessment of expressive and receptive language and stereotyped behaviors displayed by the child; in addition to observation of the child playing games, and evaluation of his/her social responsiveness whilst in the clinical room.

The language delay group comprised children with expressive and receptive language disorders and developmental speech/ language delay. Those with genetic syndromes and neurological disorders were excluded from the study, and all children with suspected ASD and language delay had a normal outcome in a hearing test.

The Childhood Autism Rating Scale (CARS) was completed by the clinician, and the Aberrant Behavior Checklist-Community (ABC) was completed by the parents. Participants were grouped into five broad diagnostic categories: (1) no diagnosis group; (2) disruptive behavior disorder (DBD) group (disor- 
ders related to conduct and/or inattention); (3) depression/ anxiety group; (4) ASD group; and (5) language delay group. Because of the small sample size in the diagnostic categories, the participants were classified in broad categories (i.e., DBD and depression/anxiety) instead of providing a comparative analysis of the DBD and depression/anxiety subgroups.

Parental informed consent and the children's verbal assent were obtained. The study protocol was approved by the institutional review board of Bezmialem Vakif University, Istanbul (Ref no: 71306642-050.01.04).

\section{Measures}

\begin{abstract}
Aberrant behavior checklist $(16,17)$
The checklist consisted of 58 items, each rated on a 4-point scale ranging from 0 , "indicating no problem" to 3 representing "severe problem." The $\mathrm{ABC}$ has the following five subcategories: 15 items representing problems with irritability, crying, agitation; 16 items related to social withdrawal and lethargy; 7 items assessing stereotypic behavior; 16 items related to problems with hyperactivity and noncompliance; and 4 items assessing inappropriate speech. Excellent validity and reliability was demonstrated in the Turkish version, which was reported to discriminate several syndromes in early childhood (18).
\end{abstract}

\section{Childhood Autism Rating Scale (19)}

CARS is a commonly used tool to assess the presence and severity of symptoms related to ASD. It can also be used to distinguish ASD from other developmental disorders. The child's behavior is rated by a trained observer on each of the 15 dimensions or symptoms. The presence or severity of each symptom is rated on a 4-point Likert scale; the maximum total score is 60 , and a 30 -point cutoff indicates the presence of ASD (20).

\section{Television-viewing-habits questionnaire and diagnostic assessments}

In terms of defining TV-viewing habits, we mainly adopted the definitions proposed by Chonchaiya et al. (13). The TV- viewing habits consisted of the average duration of time spent viewing TV and the content (what programs watched) and context (how and alone or with whom they watched) as well as the earliest age when children started watching TV. Instead of asking about the total interactive activities with their children, we only assessed the average duration the parents spent playing with the children. This is because we aimed to primarily focus on the duration that the children are likely to spend watching TV, which usually takes over the time that should be set for playing. However, we also enquired about the duration of playtime spent with siblings with the same purpose. This has been largely neglected in previous research.

\section{Statistical analysis}

One-way analysis of variance (ANOVA) or nonparametric comparison (Kruskal-Wallis test) was performed for the analysis of continuous data depending upon the homogeneity of variance and the assumption of normality in each group. The LSD (least significant difference) post hoc analysis was performed in the case of a significant difference between groups in ANOVA. The categorical variables were compared using the chi-square test. Statistical Package for the Social Sciences version 19.0 for Windows (SPSS Inc.; Chicago, IL, USA) was used for statistical analysis; $\mathrm{p}$ values $<0.05$ were considered significant, and all values reported were two-sided.

\section{Results}

\section{Characteristics of the participants}

The children's age and sex differed significantly between the groups. The children in the ASD group were the youngest (37.5 \pm 11.9 months), and those in the anxiety/ depression group were the oldest $(46.5 \pm 10.1$ months). The sex ratio (male/female) was highest in the autism group (M/F: 28/4) and the lowest in the no diagnosis group (M/F: 14/13). Other parameters showed no significant difference between the groups (Table 1).

The family and socioeconomic characteristics revealed no significant difference between the groups (Table 2).

\section{Table 1. Characteristics of the participants}

\begin{tabular}{|c|c|c|c|c|c|c|}
\hline Variables (Mean/SD) & ASD $(n=32)$ & $\operatorname{DBD}(n=28)$ & $\operatorname{LnD}(n=36)$ & Dep/Anx $(n=19)$ & No dx $(n=27)$ & $p$ \\
\hline Age (months) & $37.5(11.9)$ & $45.1(8.7)$ & $40.5(10.0)$ & $46.5(10.1)$ & $42.1(8.9)$ & 0.012 \\
\hline $\begin{array}{l}\text { First meaningful } \\
\text { word (months) }\end{array}$ & $14.3(7.0)$ & $11.0(3.6)$ & $13.6(5.6)$ & $11.7(7.0)$ & $12.3(5.4)$ & 0.350 \\
\hline $\operatorname{Sex}(M / F)$ & $28 / 4$ & $22 / 6$ & $28 / 8$ & $10 / 9$ & $14 / 13$ & 0.001 \\
\hline $\begin{array}{l}\text { Preterm } \\
\text { (GA } \leq 37 \text { weeks) }\end{array}$ & $10.8 \%$ & $15.3 \%$ & $22.9 \%$ & $15.8 \%$ & $10.5 \%$ & 0.652 \\
\hline Birth weight (g) & $3208.1(528.6)$ & $3260.0(593.4)$ & $3208.4(661.6)$ & $3214.1(403.5)$ & $3180.7(739.3)$ & 0.995 \\
\hline PND & $6.7 \%$ & $25.9 \%$ & $8.6 \%$ & $11.1 \%$ & $19.2 \%$ & 0.191 \\
\hline Past medical illness & $16 \%$ & $12.5 \%$ & $3.2 \%$ & $5.6 \%$ & $7.4 \%$ & 0.500 \\
\hline
\end{tabular}


Table 2. Parental and family characteristics

\begin{tabular}{|c|c|c|c|c|c|c|}
\hline Variables & ASD $(n=32)$ & $\mathrm{DBD}(n=28)$ & $\operatorname{LnD}(n=36)$ & $\operatorname{Dep} / \operatorname{Anx}(n=19)$ & no $d x(n=27)$ & $p$ \\
\hline Father's age (years) & $35.3(5.5)$ & $36.6(6.6)$ & $35.2(4.2)$ & $35.9(4.3)$ & $34.3(7.3)$ & 0.686 \\
\hline $\begin{array}{l}\text { Father's education } \\
\text { (above high school) }\end{array}$ & $71 \%$ & $44 \%$ & $73.6 \%$ & $53 \%$ & $61.5 \%$ & 0.134 \\
\hline Mother's age (years) & $33.5(5.5)$ & $30.9(4.9)$ & $31.6(4.4)$ & $33.0(3.9)$ & $31.0(6.8)$ & 0.273 \\
\hline $\begin{array}{l}\text { Mother's education } \\
\text { (above high school) }\end{array}$ & $63.4 \%$ & $52 \%$ & $47.1 \%$ & $64.7 \%$ & $72 \%$ & 0.319 \\
\hline Single parent & $3.2 \%$ & $11.5 \%$ & $6.1 \%$ & $15.8 \%$ & $8 \%$ & 0.548 \\
\hline $\begin{array}{l}\text { Combined parental } \\
\text { incomez (> 10000\$/ year) }\end{array}$ & $33.3 \%$ & $16.7 \%$ & $40.7 \%$ & $38.9 \%$ & $43.4 \%$ & 0.299 \\
\hline Number of siblings $(\geq 1)$ & $60.7 \%$ & $47.6 \%$ & $66.7 \%$ & $69.2 \%$ & $55 \%$ & 0.256 \\
\hline
\end{tabular}

Table 3. ABC and CARS statistics for each diagnostic group

\begin{tabular}{|c|c|c|c|c|c|c|c|}
\hline & ASD $n=32$ & DBD $n=28$ & $\operatorname{LnD} n=36$ & Dep/Anx n=19 & no dx $n=27$ & $p$ & Source of significance \\
\hline ABC-Irritability & $9.8(8.2)$ & $23.0(9.6)$ & $10.0(8.1)$ & $9.9(8.4)$ & $9.7(5.6)$ & $<0.001$ & $1: 2,2: 3,2: 4,2: 5$ \\
\hline ABC-Lethargy & $8.0(7.4)$ & $11.2(8.9)$ & $6.2(5.9)$ & $4.2(4.3)$ & $4.0(4.6)$ & $<0.001$ & $2: 3,2: 4,2: 5$ \\
\hline ABC-Stereotypic & $3.1(4.3)$ & $5.7(6.1)$ & $2.6(3.3)$ & $1.1(1.7)$ & $1.4(1.9)$ & 0.001 & $2: 3,2: 4,2: 5$ \\
\hline ABC-Hyperactivity & 14.7 (9.9) & $26.5(10.8)$ & $12.6(10.5)$ & $12.5(10.2)$ & $7.7(5.2)$ & $<0.001$ & $1: 2,2: 3,2: 4,2: 5$ \\
\hline ABC-Inap. Speech & $1.8(2.5)$ & $5.7(3.2)$ & $2.0(2.6)$ & $2.8(3.0)$ & $2.3(1.6)$ & $<0.001$ & $1: 2,2: 3,2: 4,2: 5$ \\
\hline ABC-Total & $37.8(27.8)$ & $71.0(33.9)$ & $33.4(26.0)$ & $30.6(22.8)$ & $25.2(13.4)$ & $<0.001$ & $1: 2,2: 3,2: 4,2: 5$ \\
\hline CARS & $31.1(6.9)$ & $18.0(1.9)$ & $19.0(2.8)$ & $16.3(1.2)$ & $16.6(1.8)$ & $<0.001$ & $1: 2,1: 3,1: 4,1: 5$ \\
\hline
\end{tabular}

Table 4. Television viewing habits

\begin{tabular}{|c|c|c|c|c|c|c|}
\hline & $\operatorname{ASD}(n=32)$ & DBD $(n=28)$ & $\operatorname{LnD}(n=36)$ & Dep/Anx $(n=19)$ & No dx $(n=27)$ & $p$ \\
\hline TV viewing, onset $<12$ months & $56.7 \%$ & $22.2 \%$ & $36.1 \%$ & $21.1 \%$ & $29.6 \%$ & 0.038 \\
\hline TV viewing, onset $<24$ months & $96.7 \%$ & $81.5 \%$ & $80.6 \%$ & $68.4 \%$ & $81.5 \%$ & 0.137 \\
\hline TV viewing, duration $>4$ h/day & $28.1 \%$ & $25 \%$ & $28.6 \%$ & $21.1 \%$ & $18.5 \%$ & 0.883 \\
\hline TV viewing, duration >2 h/day & $56.3 \%$ & $67.9 \%$ & $65.7 \%$ & $57.9 \%$ & $59.2 \%$ & 0.866 \\
\hline Viewing non-child TV programs & $87.5 \%$ & $50 \%$ & $65.4 \%$ & $42.9 \%$ & $33.3 \%$ & 0.003 \\
\hline No interaction during TV viewing & $62.5 \%$ & $29.2 \%$ & $38.5 \%$ & $42.9 \%$ & $38.1 \%$ & 0.197 \\
\hline Total domestic TV viewing >5h/day & $30 \%$ & $42.9 \%$ & $45.7 \%$ & $38.9 \%$ & $40 \%$ & 0.380 \\
\hline Play time with mother $>1 \mathrm{~h} /$ day & $69 \%$ & $73.1 \%$ & $61.7 \%$ & $47.3 \%$ & $76 \%$ & 0.284 \\
\hline Play time with father $>1 \mathrm{~h} /$ day & $42.3 \%$ & $45.8 \%$ & $39.4 \%$ & $35.3 \%$ & $30.5 \%$ & 0.844 \\
\hline Play time with sibling $>1 \mathrm{~h} / \mathrm{day}$ & $37 \%$ & $25 \%$ & $66 \%$ & $67 \%$ & $18 \%$ & 0.003 \\
\hline
\end{tabular}

\section{Scale scores}

All subscales differed between the groups (Table 3). The CARS scores $(\mathrm{p}<0.001), A B C$ total $(\mathrm{p}<0.001)$, and the ABS subscale scores were significantly different between groups. The post hoc analysis revealed that the $\mathrm{ABC}$ total and subscale scores were significant in the DBD group and the CARS scores were significant in the autism group (Table 3 ).

\section{Television viewing habits}

The percentage of children who started watching TV before the age of 12 months was significantly different between 
groups ( $\mathrm{p}=0.038$ ). The ASD group differed significantly from the $\mathrm{DBD}$, anxiety/depression, and no diagnosis groups.

The TV-viewing time and interaction while watching TV was not different between the groups; however, the content of TV showed a statistically significant difference between the diagnostic groups $(\mathrm{p}=0.003)$. Children with ASD watch more adult programs than the rest of the sample, except the other diagnosis group.

The total time children spend playing with their parents did not differ significantly between the groups, but the total time playing with their siblings was significantly different between the groups $(\mathrm{p}=0.003)$. The children in the depression/anxiety group and those in the other diagnosis group were spending significantly more hours playing with their siblings than the rest of the samples (Table 4).

\section{Discussion}

To the best of our knowledge, TV-viewing habits in preschool children with a variety of clinical diagnoses, including the ASD, language delay, DBD, depression/anxiety, and nodiagnosis clinical groups, have not been previously studied. Results based on the parental report show different TV-viewing patterns among preschool children with different diagnoses. Infants in the first 12 months of their lives, who later had been diagnosed with ASD, vastly outnumber those in the other diagnostic groups in terms of the earlier onset of and adult-oriented content of TV viewing, except those with language delay. This similarity between the ASD and delayed language groups is consistent with the findings of the study by Chonchaiya et al. (13).

According to the existing literature, different diagnostic groups, especially those with language delay (9-11), attention deficit hyperactive disorder (12), and ASD (13) show different patterns of TV-viewing habits. The findings presented here are grossly in line with the existing research. The content of viewing (adult programs) differed among the diagnostic groups $(\mathrm{p}=0.003)$, but the context (co-viewing with adults) only differed significantly between subjects with ASD (the least co-viewing) and DBD (the most co-viewing).

An interesting finding of our study is that the duration of playtime with parents did not differ among the diagnostic groups. However, the time spent with siblings in the ASD group was significantly lower compared to the language delay group and depression/anxiety group. As deficits in social interaction form one of the core symptoms of ASD, it is not surprising to see that the sibling interaction in this group is grossly restricted. It is worthwhile to mention that the family size and the number of siblings did not differ among the groups. Children with language delay and those with depression/anxiety had longer playtime with siblings compared with the other three groups.

Our results demonstrated that a vast majority of the participants, including children with no psychiatric diagnosis, started watching TV before the age of 24 months. Guidelines about the media use advice against "screen time" for those under age of 2 years and restrict the "screen time" to a maximum of 2 hours a day for children above the 2 years of age (21, 22). However, more recent recommendations draw attention to family participation, which is reported to facilitate learning and social interactions. Parents are therefore encouraged to co-play video games with their older children when necessary and co-view screens with the younger ones (23).

Although the age when children start watching TV did not largely differ between groups in the first 2 years of their lives, the difference was statistically significant for the ASD and language delay groups in the first 12 months. This indicates that the children with ASD and language delay started viewing TV earlier than the other groups. Based on the findings presented here, we propose that the currently suggested "two years as the minimum age for TV-viewing" needs to be lowered and parents to warned and educated about the deleterious effect of TV viewing and exposure to screens on healthy development of their children.

\section{Study limitations}

The present study has several limitations. Although this is the first study that evaluated TV-viewing habits in a number of diagnostic groups in a clinical setting, a small sample size and the selection of clinical sampling limits the generalizability of the results to the non-clinical population. Although we used the Denver-II (23) developmental test for developmental screening, it was not performed to assess language delay in suspected participants because of lack of resources (i.e., staffing and funding). Lack of standardized ASD assessment is another limitation of the present study; however, it is important to mention that such standardized diagnostic tools (ADOS, DISCO, etc.) have not been validated in Turkish language. We therefore conducted a Diagnostic and Statistical Manual of Mental Disorders-5based detailed clinical examination and used the CARS for diagnostic assessment of patients with ASD and language delay. Findings about the TV-viewing habits were based on parental reports and checklists. Lack of a more objective measure, such as video recordings or direct observations in the home setting, can also be listed as a study limitation. The diagnostic groups are not matched in terms of the age and sex; hence, the results need to be interpreted with caution. Overall, the results should be interpreted carefully because of the crosssectional nature of the present study. Therefore, prospective, longitudinal studies are required to conclude a cause-effect relationship.

\section{Conclusion}

The TV-viewing habits appear to be significantly associated with language delay and ASD and we suggest that TV viewing habits should be included in the routine psychiatric assessment, particularly for infant mental health. Parents need to be provided with appropriate guidance. 
Ethics Committee Approval: Ethics committee approval was received for this study from the ethics committee of Bezmialem Vakif University School of Medicine (Reference no: 71306642-050.01.04).

Informed Consent: Written informed consent was obtained from the parents of the patients who participated in this study.

Peer-review: Externally peer-reviewed.

Author Contributions: Concept - A.C.Ö.; Design - A.C.Ö.; Supervision - A.C.Ö., V.G.; Data Collection and/or Processing A.C.Ö.; Analysis and/or Interpretation - A.C.Ö., V.G.; Literature Search - A.C.Ö.; Writing Manuscript - A.C.Ö., V.G.; Critical Review - A.C.Ö., V.G.

Conflict of Interest: No conflict of interest was declared by the authors.

Financial Disclosure: The authors declared that this study has received no financial support.

Etik Komite Onayı: Bu çalışma için etik komite onayı Bezmialem Vakıf Üniversitesi Tip Fakültesi'nden (Referans no: 71306642 050.01.04) alınmıştır.

Hasta Onamı: Yazılı hasta onamı bu çalışmaya katılan hastaların ailelerinden alınmıştır.

Hakem Değerlendirmesi: Dış bağımsız.

Yazar Katkıları: Fikir - A.C.Ö.; Tasarım - A.C.Ö.; Denetleme A.C.Ö., V.G.; Veri Toplanması ve/veya İşlemesi - A.C.Ö.; Analiz ve/veya Yorum - A.C.Ö., V.G.; Literatür Taraması - A.C.Ö.; Yazıyı Yazan - A.C.Ö., V.G.; Eleştirel İnceleme - A.C.Ö., V.G.

Çıkar Çatışması: Yazarlar çıkar çatışması bildirmemişlerdir.

Finansal Destek: Yazarlar bu çalışma için finansal destek almadıklarını beyan etmişlerdir.

\section{References}

1. Christakis DA, Ebel BE, Rivara FP, Zimmerman FJ. Television, video, and computer game usage in children under 11 years of age. J Pediatr 2004; 145: 652-6. [CrossRef]

2. Donald F. Roberts UGF, Victoria Rideout Generation M: media in the lives of 8-18 year olds. Menlo Park, CA: Kaiser Family Foundation; 2006.

3. Christakis DA, Garrison MM, Zimmerman FJ. Television viewing in child care programs: A national survey. Communication Rep 2006; 19: 111-20. [CrossRef]

4. Christakis DA. The effects of infant media usage: what do we know and what should we learn? Acta Paediatr 2009; 98: 8-16.

5. Vandewater EA, Rideout VJ, Wartella EA, Huang X, Lee JH, Shim MS. Digital childhood: electronic media and technology use among infants, toddlers, and preschoolers. Pediatrics 2007; 119: e1006-e15.
6. Zimmerman FJ, Christakis DA, Meltzoff AN. Television and DVD/video viewing in children younger than 2 years. Arch Pediatr Adolesc Med 2007; 161: 473-9. [CrossRef]

7. Mendelsohn AL, Berkule SB, Tomopoulos S, Tamis-LeMonda CS, Huberman HS, Alvir J, et al. Infant television and video exposure associated with limited parent-child verbal interactions in low socioeconomic status households. Arch Pediatr Adolesc Med 2008; 162: 411-7. [CrossRef]

8. Kuhl PK, Tsao FM, Liu HM. Foreign-language experience in infancy: Effects of short-term exposure and social interaction on phonetic learning. Proc Natl Acad Sci U S A 2003; 100: 9096-101. [CrossRef]

9. Zimmerman FJ, Christakis DA, Meltzoff AN. Associations between media viewing and language development in children under age 2 years. J Pediatr 2007; 151: 364-8. [CrossRef]

10. Chonchaiya W, Pruksananonda C. Television viewing associates with delayed language development. Acta Paediatrica 2008; 97: 977-82. [CrossRef]

11. Linebarger DL, Walker D. Infants' and toddlers' television viewing and language outcomes. American Behavioral Scientist 2005; 48: 624-45. [CrossRef]

12. Christakis DA, Zimmerman FJ, DiGiuseppe DL, McCarty CA. Early television exposure and subsequent attentional problems in children. Pediatrics 2004; 113: 708-13. [CrossRef]

13. Chonchaiya W, Nuntnarumit P, Pruksananonda C. Comparison of television viewing between children with autism spectrum disorder and controls. Acta Paediatr 2011; 100: 1033-7. [CrossRef]

14. Thomas JM, Benham AL, Gean M, Luby J, Minde K, Turner $S$, et al. Practice parameters for the psychiatric assessment of infants and toddlers (0-36 months). J Am Acad Child Adolesc Psychiatry 1997; 36: 21S-36S.

15. Association AP. DSM 5: American Psychiatric Association; 2013.

16. MianEL G, SINGH NN. The aberrant behavior checklist: a behavior rating scale for the assessment of treatment effects. 1985.

17. Aman MG, Singh NN, Stewart AW, Field CJ. Psychometric characteristics of the aberrant behavior checklist. Am J Ment Defic 1985; 89: 492-502.

18. Karabekiroglu K, Aman MG. Validity of the aberrant behavior checklist in a clinical sample of toddlers. Child Psychiatry Hum Dev 2009; 40: 99-110. [CrossRef]

19. Schopler E, Reichler RJ, DeVellis RF, Daly K. Toward objective classification of childhood autism: Childhood Autism Rating Scale (CARS). J Autism Dev Disord 1980; 10: 91-103. [CrossRef]

20. Sucuoglu B, Oktem F, Akkok F, Gokler B. A study of the scales for the assessment of the children with autism. Psikiyatri, Psikoloji, Psikofarmakoloji (3P) 1996; 4: 116-21.

21. Brown A. Media use by children younger than 2 years. Pediatrics 2011; 128: 1040-5. [CrossRef]

22. Strasburger VC, Hogan MJ, Mulligan DA, Ameenuddin N, Christakis DA, Cross C, et al. Children, adolescents, and the media. Pediatrics 2013; 132: 958-61. [CrossRef]

23. Brown A, Shifrin D, Hill D. Beyond 'turn it off: How to advise families on media use. AAP News 2015; 36: 54. 